\begin{tabular}{lcr}
\hline & \multicolumn{2}{c}{ ANNALES } \\
& UNIVERSITATIS MARIAE CURIE-SKŁODOWSKA & \\
VOL. II & LUBLIN - POLONIA & 2017 \\
\hline
\end{tabular}

Małgorzata Podolak

Uniwersytet Marii Curie-Skłodowskiej

\title{
Pozycja ustrojowa głowy państwa w Bośni i Hercegowinie
}

\section{Specyfika systemu politycznego państwa}

Bośnia i Hercegowina powstała w wyniku rozpadu Socjalistycznej Federacyjnej Republiki Jugosławii (SFRJ), który nastąpił na początku lat dziewięćdziesiątych ubiegłego stulecia. Współcześnie BiH jest państwem o najbardziej skomplikowanej strukturze ustrojowej na Bałkanach Zachodnich. Porządek ustrojowy wypracowany podczas negocjacji pokojowych w Dayton w roku 1995 miał na celu stworzenie ram, w obrębie których mogłyby funkcjonować trzy pozostające w stanie wojny domowej wspólnoty etniczne i polityczne: Bośniacy, Chorwaci i Serbowie. Bośnia i Hercegowina w kształcie po podpisaniu pokoju w Dayton posiada jeden z najbardziej skomplikowanych ustrojów politycznych w na świecie ${ }^{1}$.

Porozumienie z Dayton miało charakter umowy międzynarodowej². Oprócz stron bośniackiego konfliktu (Bośniaków, Serbów i Chorwatów) oraz przywódców Chorwacji i Jugosławii uczestniczyli w nim członkowie Grupy Kontaktowej (USA, Rosja, Wielka Brytania, Francja, RFN i Włochy) oraz Specjalny Negocjator Unii Europejskiej. Składało się z jedenastu niezbyt rozbudowanych artykułów oraz

1 W. Stanisławski, Bośnia i Hercegowina, [w:] Bałkany Zachodnie a integracja europejska. Perspektywy i implikacje, red. R. Sadowski, J. Muś, Urząd Komitetu Integracji Europejskiej, Warszawa 2008, s. 42.

2 K. Krysieniel, System wyborczy w Bośni i Hercegowinie - spojrzenie krytyczne, „Przegląd Prawa Konstytucyjnego", 2010, nr 1, s. 166. 
takiej samej liczby aneksów, zawierających szczegółowe informacje i regulacje $\mathrm{e}^{3}$. Poszczególne aneksy obejmowały najważniejsze kwestie mające przyczynić się do ustabilizowania sytuacji w państwie. Do kluczowych można bez wątpienia zaliczyć Aneks nr IV (Konstytucję) oraz Aneks nr X (Cywilną implementację). Pierwszy z wyżej wymienionych zawierał tekst ustawy zasadniczej, drugi natomiast powoływał do życia instytucję Wysokiego Przedstawiciela Wspólnoty Międzynarodowej (The High Representative of International Community, OHR5), który miał nadzorować wprowadzanie porozumienia w życie ${ }^{4}$.

W przypadku państw postjugosłowiańskich wpływ na kształtowanie się przyszłych systemów politycznych miało zróżnicowanie etniczno-religijne tego regionu ${ }^{5}$. Bośnia i Hercegowina jest państwem złożonym, zamieszkałym przez trzy konstytutywne narody, wymienione z nazwy w preambule konstytucji: Boszniaków, Chorwatów i Serbów. Składa się z dwóch jednostek: Republiki Serbskiej (RS) i zdominowanej przez ludność muzułmańską i chorwacką Federacji Bośni i Hercegowiny (FBiH) oraz Dystrykt Brčko, który znajdował się, stanowiąc kondominium, pod wspólnym zarządem obu entitetów, a od 2000 roku posiada szeroką autonomię. Skomplikowana sytuacja narodowościowa przenosi się na organy administracji publicznej, która oparta jest na parytetach narodowościowych ${ }^{6}$.

Każdy z podmiotów ma własnych prezydentów, parlamenty i rządy, odrębne aparaty policyjne i większość struktur administracyjnych. Osobnym organem władzy jest Urząd Wysokiego Przedstawiciela, wybierany przez tzw. Radę ds. Wcielenia Pokoju, nadzoruje proces demokratyzacji w BiH i od 1999 roku posiada tzw. uprawnienia bońskie, dające mu prawo do odwoływania miejscowych polityków i urzędników łamiących postanowienia pokojowe z Dayton. Szczegółowy zakres uprawnień jest stale dyskutowany, a same uprawnienia - kwestionowane przez miejscowe, głównie serbskie, elity polityczne ${ }^{7}$.Za podjęte decyzje Wysoki Przedstawiciel nie odpowiada przed władzami bośniackimi ${ }^{8}$.

3 Dayton Peace Agreement, http://peacemaker.un.org/sites/peacemaker.un.org/files/BA_ 951121_DaytonAgreement.pdf, dostęp 30 VI 2016.

4 Zob., K. Krysieniel, Ucieczka od Dayton? Bośnia i Hercegowina w procesie przemian ustrojowych, [w:] Polska i Europa Środkowa. Demokratyzacja, konsolidacja, europeizacja, red. E. Nowak, R. Riedel, Wydawnictwo UMCS, Lublin 2010, s. 432.

5 U. Vlaisavlević, Bośnia i Hercegowina: ciagtość etnopolityki w wieku integracji europejskiej, [w:] Rok 1989 - 20 lat później: kraje postkomunistyczne a integracja europejska, red. M. Ebertowski, Przedstawicielstwo Fundacji im. H. Bölla, Warszawa 2009, s. 177.

6 Zob. M. Vanderwerf, National Identity in Bosnia-Herzegovina. Part 1: Framework for Exploration, http://www.globalmissiology.org/portugues/docs_pdf/featured/vanderwerf_national _identity_bosnia-herzegovina_part1_2_2009.pdf, dostęp 10 X 2015.

7 W. Stanisławski, op. cit., s. 43.

8 D. Gibas-Krzak, Bośnia i Hercegowina: determinanty dziejów. Pomiędzy Serbami, Chorwatami a supremacją Muzułmanów, Wydawnictwo im. Stanisława Podobińskiego, Częstochowa 2016, s. 191-192. 
Zgodnie z konstytucją, BiH jest państwem demokracji parlamentarnej. Chociaż prawnie jest kontynuatorką byłej jugosłowiańskiej republiki Bośni i Hercegowiny, w konstytucji daytonowskiej $\mathrm{BiH}$ nie jest sprecyzowane, czy jest federacją, konfederacją, a nawet w nazwie nie ma określenia „republika”, a na pewno nie „republika federacyjna”.

Porozumienie z Dayton zawierało rozwiązania, które miały być tymczasowe, tj. miały służyć zakończeniu wojny ${ }^{10}$. Owa „tymczasowość” trwa jednak nadal, mimo braku powszechnej akceptacji. Nie rozwiązano między innymi takich problemów, jak: powrót uchodźców, segregacja etniczna, rozliczenie zbrodni wojennych, nacjonalizmy. Nie stworzono zatem podstaw do budowania nowoczesnego państwa ${ }^{11}$. Z drugiej strony pojawiają się głosy, nie tylko wśród lokalnych nacjonalistów, optujące za podziałem państwa bośniackiego (takie głosy pojawiały się na przykład wśród bośniackich Serbów po ogłoszeniu niepodległości przez Kosowo, uznanym przez wiele państw). Jak zauważył Ivo Banac, dopóki istnieć będą nacjonaliści ze swoim dążeniem do budowania homogenicznego etnicznie państwa, dopóty wątpliwa będzie ciągłość państwowości Bośni i Hercegowiny, której, nota bene, „wiodło się najlepiej w ramach systemów imperialnych - Imperium Otomańskiego, monarchii Habsburgów lub w ramach systemów, które relatywizowały siłę nacjonalizmu, jak Jugosławia marszałka Tito"12.

Według Krzysztofa Krysieniela rozwiązania przyjęte w 1995 roku wykazują kilka charakterystycznych cech:

a) uregulowanie materii prawno-konstytucyjnej porozumieniem międzynarodowym;

b) etnizację ustrojodawcy poprzez odsunięcie na plan dalszy abstrakcyjnego obywatela jako nosiciela władzy ustrojodawczej;

c) tymczasowość rozwiązań, przekształconą w trwały system prawno-konstytucyjny;

${ }^{9}$ M. Babić, Bośnia i Hercegowina - specyfika systemu politycznego, [w:] Małe państwa Europy, specyfika systemu politycznego i aktywności międzynarodowej, red. D. Popławski, Oficyna Wydawnicza Astra-IR, Warszawa 2009, 235-253.

${ }^{10}$ Przykładem takiej „trwałej prowizorki” jest zapewnienie Bośni i Hercegowinie dostępu do morza. Odcinek wybrzeża o długości $17 \mathrm{~km}$, należący do Bośni, przecina terytorium Chorwacji na dwie części, co oznacza, że każdy, kto podróżuje z północy na południe Chorwacji, dwukrotnie musi przekraczać granicę bośniacko-chorwacką.

${ }_{11}$ Zob. O. Yiftachel, Etnocracy. Land and Indentity Polititcs In Israel/Palestine, University of Pennsylvania Press, Philadelfia 2006, s. 16.

${ }^{12}$ I. Banac, What happened in the Balkans (or rather ex Yugoslavia)?, "East European Politics and Societies", 2009, nr 4, s. 477-478; J. Olchowski, K. Pawłowski, Region Europy Południowo -Wschodniej, [w:] Regiony w stosunkach międzynarodowych, red. I. Topolski, H. Dumała, A. Dumała, Wydawnictwo UMCS, Lublin 2009, s. 94. 
d) usankcjonowanie bezprawia i przekształcenie efektów konfliktu i zbrodni wojennych w stosunki publiczno-prawne;

e) etniczną demokrację, która wymaga osiągnięcia etnicznego porozumienia we wszystkich sprawach państwowych, połączoną z permanentnym konfliktem między przedstawicielami narodów konstytutywnych (Boszniakami, Serbami i Chorwatami);

f) etniczny determinizm przy podejmowaniu decyzji w organach władzy;

g) aktywną obecność czynnika zewnętrznego przy kierowaniu państwem;

h) utratę suwerenności wewnętrznej poprzez osłabianie organów władzy państwowej;

i) zawieszenie aktywnej ochrony oficjalnie zaakceptowanych praw człowieka;

j) sprzeczności między deklarowanymi pryncypiami a podstawowymi rozwiązaniami konstytucyjnymi ${ }^{13}$.

W ustawie zasadniczej bardzo często znajdują się odwołania do gwarancji przestrzegania praw i zachowania odrębności Republiki Serbskiej i Federacji $\mathrm{BiH}$. Równie często pojawiają się zapewnienia praw narodom konstytutywnym, co jednocześnie ogranicza, a czasem wyklucza (na przykład w Prezydium) możliwość wyboru reprezentantów grup etnicznych innych niż bośniacka, serbska i chorwacka. Ordynacja wyborcza wprost zawiera zapis, iż odmowa podania przynależności narodowej oznacza utratę biernego prawa wyborczego do tych organów, gdzie funkcjonuje z góry określony parytet ${ }^{14}$.

Porozumienie z Dayton do dziś wzbudza wiele kontrowersji, co nie zmienia faktu, że jednocześnie reguluje wewnątrzpolityczną organizację państwa. Po tym, jak w trakcie wojny kraj ten rozpadł się zarówno w sensie prawnym, politycznym, jak i etnicznym, dzisiaj - pod hasłami politycznej integracji - poddawany jest sztucznej reanimacji instytucjonalnej pod patronatem społeczności międzynarodowej. BiH jest bezprecedensowym przykładem państwa istniejącego zgodnie z zasadą: ,jeden kraj - dwa podmioty - trzy konstytutywne narody”, co w dłuższej perspektywie podtrzymuje nieustające procesy dezintegracyjne na płaszczyźnie wewnętrznej ${ }^{15}$.

Do podstawowych elementów dysfunkcjonalnych obecnych w systemie politycznym Bośni i Hercegowiny można zaliczyć:

${ }^{13}$ K. Krysieniel, System wyborczy w Bośni i Hercegowinie - spojrzenie krytyczne, „Przegląd Prawa Konstytucyjnego", 2010, nr 1, s. 167.

${ }^{14}$ K. Krysieniel, Wielokulturowość Bośni i Hercegowiny i jej wptyw na ustrój państwa, [w:] Wspótczesne państwo. Wybrane problemy, red. S. Wróbel, Wyższa Szkoła Bankowa, Poznań 2009, s. 345.

${ }^{15}$ M. Babić, Bałkanizacja czy europeizacja? Bośnia i Hercegowina w perspektywie europejskiej, [w:] Konflikty narodowe i europejskie aspiracje państw batkańskich, red. M. Filipowicz, Lublin, Instytut Europy Środkowo-Wschodniej, rok 9, 2011, zeszyt 2, s. 138-139. 
a) stworzenie dwóch jednostek (entiteti) o odmiennej strukturze terytorialno-administracyjnej - scentralizowanej Republiki Serbskiej (obejmującej 49\% obszaru państwa) oraz Federacji Bośni i Hercegowiny, składającej się z dziesięciu kantonów (51\%);

b) przekształcenie Bośni i Hercegowiny w półprotektorat poprzez powołanie instytucji Wysokiego Przedstawiciela Wspólnoty Międzynarodowej; w grudniu 1997 roku rozszerzono jego kompetencje o tak zwane uprawnienia bońskie, co dało mu możliwość dowolnego kształtowania prawa (w tym konstytucji jednostek oraz ustaw), tworzenia i obsadzania organów władzy i urzędów, dymisjonowania polityków, wetowania kandydatów na stanowiska publiczne oraz karania partii politycznych ${ }^{16}$;

c) brak decyzji co do przynależności terytorialnej strategicznie położonego miasta Brčko; ostatecznie w 1999 roku został utworzony Dystrykt Brčko, posiadający własny statut i organy władzy ${ }^{17}$, podlegający bezpośrednio Sarajewu; dopiero w 2009 roku istnienie tej specyficznej jednostki zostało uwzględnione w konstytucji;

d) słabe władze centralne, co przełożyło się na przykład na trudności z ujednoliceniem wojska i służb policyjnych, kontrolą graniczną, wprowadzeniem wspólnej waluty, a nawet paszportów;

e) różnice w systemach politycznych Republiki Serbskiej i Federacji, co prowadzi do dyskryminacji na tle narodowościowym, religijnym, a nawet w szkolnictwie czy ekonomii;

f) niezwykle skomplikowany sposób podejmowania decyzji na poziomie władz centralnych oraz jednostek, zawierający możliwość zastosowania weta przez przedstawicieli któregoś z narodów konstytutywnych w obronie tak zwanych żywotnych (witalnych) interesów ${ }^{18}$.

Na poziomie ogólnopaństwowym działa Bank Centralny, Sąd Najwyższy oraz Trybunał Konstytucyjny, rozstrzygający między innymi spory między entitetami, a także między entitetami a centrum i innymi instytucjami państwowymi. Na poziomie entitetów także działają dwuizbowe parlamenty, urzędy prezydentów i ich zastępców oraz rządy (w FBiH 13 ministerstw, w RS 16), a także Sądy Konstytucyjne i Najwyższe. FBiH dzieli się jeszcze na mniejsze jednostki administracyjne (bos. kanton/chr. županija), których zakres kompetencji znacznie przekracza przypisany zwykłemu średniemu szczeblowi administracji, między innymi posiadają

${ }_{16}$ T.K. Vogel, Bosnia and Herzegovina: The Challenge of Legitimacy, „Working Paper”, 2006 nr 2, s. 6.

${ }_{17}$ Zob szerzej: M. Fiszer, Proces kształtowania się statusu Dystryktu Brczko po zakończeniu konfliktu w Bośni i Hercegowinie, „Poliarchia”, 2016, nr 1(6), s. 113-131.

${ }^{18}$ K. Krysieniel, System wyborczy w Bośni i Hercegowinie... op. cit., s. 169. 
swoje Zgromadzenia Kantonalne oraz rządy (na przykład rząd Kantonu Sarajewo posiada 12 ministerstw). Oba podmioty, a także kantony w Federacji, posiadają własne konstytucje. Entitety mają prawo, szanując suwerenność i integralność terytorialną $\mathrm{BiH}$, nawiązywać kontakty dwustronne i podpisywać umowy z innymi państwami i organizacjami międzynarodowymi. Artykuł 1 ust. 4. stanowi, że istnieje możliwość swobodnego poruszania się po terytorium całego kraju osób, towarów i usług, a żaden z entitetów nie może wprowadzić kontroli na granicy między jednostkami. W artykule 5 można natomiast przeczytać, że żaden z entitetów nie może użyć siły przeciw drugiemu, a jego siły zbrojne nie mogą wkroczyć na terytorium drugiego lub pozostawać w jego granicach bez zgody jego rządu i zgody Prezydium $\mathrm{BiH}^{19}$.

\section{Wybór głowy państwa}

W roku 1953 wprowadzono w byłej Jugosławii urząd Prezydenta. Funkcję tę pełniło kolektywne Prezydium Socjalistycznej Federacyjnej Republiki Jugosławii (SFRJ), składające się z reprezentantów poszczególnych republik oraz okręgów autonomicznych (to jest Wojwodiny oraz Kosowa). Na czele prezydium stał Tito pełniący funkcję dożywotniego prezydenta. Po jego śmierci w 1980 roku funkcję przewodniczącego Prezydium pełnili rotacyjnie reprezentanci republiki ${ }^{20}$. Konstytucja Bośni i Hercegowiny dostarcza jasno wyznaczonych zasad składu narodowościowego trzyosobowej Prezydencji ${ }^{21}$. Skład tego ciała odzwierciedla podział terytorialny kraju. Art. V stanowi, że Prezydencja Bośni i Hercegowiny składa się z trzech członków: jednego Boszniaka i jednego Chorwata, wybranych bezpośrednio z Federacji BiH, oraz Serba wybranego bezpośrednio z Republiki Serbskiej ${ }^{22}$. Członkowie Prezydium pełnią rotacyjnie, zmieniając się co osiem miesięcy, funkcje Przewodniczącego Prezydium i jego zastępców.

Sposób wyboru członków kolegialnej głowy państwa szczegółowo regulują przepisy Prawa wyborczego Bośni i Hercegowiny ${ }^{23}$. Członkowie Prezydium wybierani są w głosowaniu powszechnym i bezpośrednim. W Republice Serbskiej

${ }^{19}$ B. Pomykalska, Suwerenne państwo pod nadzorem. Rzeczywistość polityczna Bośni i Hercegowiny 17 lat po Dayton, „Państwo i Społeczeństwo”, 2011 (XI), nr 4, s. 140-141.

${ }^{20} \mathrm{~J}$. Wojnicki, Prawo wyborcze na urzad prezydenta republiki w Republice Serbii, [w:] Prawo wyborcze na urzad prezydenta w państwach europejskich, red. S. Grabowska, R. Grabowski, Wolters Kluwer Polska, Warszawa 2007, s. 168.

${ }^{21}$ Constitution of Bosnia and Herzegovina, strona internetowa Urzędu Wysokiego Przedstawiciela, http://www.ohr.int, dostęp 14 VII 2015.

${ }^{22}$ J. Muś, Bośnia po wyborach, „Stosunki Międzynarodowe”, 2010, nr 69, s. 96.

${ }^{23}$ Rules of Procedure of Presidency of Bosnia and Herzegovina, http://www.predsjednistvobih.ba, dostęp 15 VII 2017. 
mandat zdobywa ten kandydat (Serb), który uzyskał największą liczbę głosów. Natomiast w Federacji za wybranych uważa się tych kandydatów - jednego Bośniaka i jednego Chorwata - którzy otrzymali najwięcej głosów spośród startujących z danego narodu konstytutywnego. Warto podkreślić, że każdy z wyborców w tej jednostce dysponuje tylko jednym głosem. Ponieważ nie ma przymusu głosowania zgodnie z przynależnością etniczną (Bośniak może oddać swój głos na kandydata chorwackiego), może dojść do sytuacji, w której przedstawiciel jednego narodu będzie wybrany głosami wyborców innego narodu konstytutywnego ${ }^{24}$. Ta sama osoba nie może być członkiem Prezydium więcej niż dwa razy z rzędu.

W społeczeństwie rozbitym przez wojnę oznacza to, że każdy kandydat będzie poszukiwał wsparcia wśród swoich rodaków. Oczywiście od tej reguły istnieją wyjątki - w czasie wyborów w 2006 i 2010 roku zwycięzcą reprezentującym chorwacką część społeczeństwa okazał się bośniacki Chorwat Želijko Komšić. Dotychczasowa praktyka pokazuje, że elektorat będzie kierował się w czasie wyborów względami narodowościowymi jako decydującymi o reprezentacji lub ochronie interesów danej grupy (etnicznej), będącymi, zgodnie z przyjętą logiką, w zasadniczym konflikcie z interesami pozostałych grup. W konstytucji bowiem założono, że Chorwat nie jest w stanie reprezentować interesu Boszniaków, tak samo jak Serb nie jest w stanie reprezentować interesów Chorwatów itd. Konstytucja pośrednio pogłębia istniejące podziały etniczne. Trójka Prezydencji ma za zadanie zapewnić, że interes żadnego z trzech narodów konstytutywnych nie jest zagrożony ${ }^{25}$.

Wybory powinny się odbyć w pierwszą niedzielę października, aby tym sposobem uprzedzić wygaśnięcie mandatu. Centralna Komisja Wyborcza jest zobowiązana do poinformowania wyborców o terminie przeprowadzenia wyborów co najmniej 150 dni przed ich datą, z tym że jeżeli w tym dniu wypada święto konstytucyjne któregoś z narodów $\mathrm{BiH}$, termin wyborów wyznacza się na najbliższą niedzielę ${ }^{26}$.

Kandydat, chcący uzyskać pozwolenie na kandydowanie do prezydencji, musi dostarczyć odpowiedni wniosek komisji, a wraz z nim przedłożyć 1500 podpisów obywateli ze spisu wyborców posiadających prawo wyborcze. Jeżeli kandydat piastuje już urząd, na który chce być ponownie wybrany, nie musi przedkładać podpisów. Kandydat musi także przedłożyć Centralnej Komisji

${ }^{24}$ K. Krysieniel, W cieniu Dayton. Bośnia i Hercegowina między etnokracja $i$ demokracja konsocjalna, Wydawnictwo Sejmowe, Warszawa 2012, s. 264.

${ }^{25}$ J. Muś, Bośnia po wyborach, „Stosunki Międzynarodowe”, 2010, nr 69, s. 97.

${ }^{26}$ A. Frankiewicz, Prawo wyborcze do prezydencji w Bośni i Hercegowinie, [w:] Prawo wyborcze na urzad prezydenta w państwach europejskich, red. S. Grabowska, R. Grabowski, Wolters Kluwer Polska, Warszawa 2007, s. 48. 
Wyborczej raport finansowy za okres trzech miesięcy przed dniem zgłoszenia chęci kandydowania, a jeżeli zostanie wybrany na urząd - przedkłada także raport za trzydzieści dni przed ogłoszeniem wyników wyborów. Raport ten obejmuje oświadczenie o wysokości dochodów, a także o oszczędnościach, dobrach materialnych oraz posiadanych nieruchomościach ${ }^{27}$.

Prezydent staje się konstytucyjnym organem państwowym z chwilą objęcia urzędu. Objęcie urzędu oznacza także rozpoczęcie kadencji prezydenta. Moment objęcia urzędu jest najczęściej określany w przepisach konstytucji, niekiedy może wynikać z norm zwyczajowych. Rozwiązanie konstytucyjne objęcia urzędu wiąże się ze złożeniem przysięgi.

W Bośni i Hercegowinie w myśl przepisów Zasad Postępowania nowo wybrana prezydencja zostaje zwołana przez przewodniczącego odchodzącej prezydencji w terminie nie później niż piętnaście dni od zatwierdzenia wyników wyborczych. Spotkanie odbywa się w siedzibie prezydencji w Sarajewie. Każdy z członków prezydencji wypowiada wtedy, a następnie podpisuje przysięgę następującej treści: „Niniejszym przysięgam, że będę sumiennie wypełniał powierzone mi obowiązki, przestrzegał konstytucji, wprowadzał w życie General Framework Agrement wraz z jego wszystkimi aneksami, będę chronił i promował prawa człowieka i podstawowe wolności oraz troszczył się o interesy i równość wszystkich ludzi i obywateli"28.

Zaprzysiężenie stanowi punkt zwrotny w sprawowaniu mandatu i uprawnieniu prezydencji do działania. Do dnia zwołania nowej prezydencji i złożenia przysięgi jej członkowie nie podejmują żadnych działań, natomiast dotychczasowa prezydencja uprawniona jest do wykonywania jedynie koniecznych i pilnych zadań, które mieszczą się w zakresie rutynowych działań prezydencji. Od momentu zaprzysiężenia wybiera się spośród członków prezydencji przewodniczącego. Przewodniczącym zostaje w pierwszej kolejności ten jej członek, który uzyskał w wyborach największą liczbę głosów ${ }^{29}$.

Instytucja incompatiblitas, czyli zakaz łączenia przez jedną osobę pewnych funkcji i stanowisk publicznych, obecna jest niemal we wszystkich demokratycznych konstytucjach świata. Konstrukcja instytucji niepołączalności była rezultatem poszukiwania rozwiązań najlepiej służących realizacji podziału władzy $\mathrm{w}$ aspekcie personalnym, chociaż obecnie nie jest uznawana za niezbędny element tej koncepcji. Reguła incompatibilitas obejmuje także instytucję prezydenta

${ }^{27}$ Ibidem, s. 48.

${ }^{28}$ Rules of Procedure of Presidency of Bosnia and Herzegovina, http://www.predsjednistvobih.ba, dostęp 15 VII 2017.

${ }^{29}$ A. Frankiewicz, op. cit., s. 51-52. 
i oznacza niepołączalność urzędu prezydenta z innym stanowiskiem w państwie. Konstytucyjne rozstrzygnięcie o zakazie łączenia stanowiska prezydenta $\mathrm{z}$ innymi funkcjami ma zabezpieczać przed nadmierną koncentracją władzy w ręku jednej osoby, a także chronić prestiż i autorytet urzędu prezydenta, zapobiegać podważaniu majestatu urzędu stanowiącego uosobienie państwa ${ }^{30}$. Prezydent, angażując się w działalność publiczną, która narzuca stosunki zależności czy podporządkowania, mógłby tracić niezależność, bezstronność i samodzielność, co z kolei mogłoby rodzić podejrzenia, że nie wykonuje swoich funkcji w sposób całkowicie wolny i bezinteresowny. Zasada niepołączalności nie oznacza niewybieralności, nie zabrania więc urzędującemu prezydentowi kandydowania w wyborach parlamentarnych. Dopiero wybór urzędującego prezydenta na posła lub senatora powodowałby konieczność opowiedzenia się za mandatem parlamentarnym lub dotychczasowym urzędem. Wydaje się jednak, że ubieganie się urzędującego prezydenta o mandat parlamentarny, prawnie niezabronione, godziłoby w rangę i powagę urzędu ${ }^{31}$.

W Bośni i Hercegowinie prawo wyborcze ustanawia ograniczenia wobec osób zamierzających kandydować, przewidując zasadę incompatibilitas, wyrażającą się w zakazie kandydowania do objęcia funkcji publicznych między innymi: sędziom sądów powszechnych i konstytucyjnych, prokuratorom, adwokatom, rzecznikom, policjantom, wojskowym i pracownikom służb wywiadowczych, dyplomatom, konsulom - chyba że przed wyborami zrezygnują z zajmowanego stanowiska lub prawo odnoszące się do ich zawodu dopuszcza kandydowanie. Nikt też nie może zostać kandydatem ani sprawować mandatu czy jakiejkolwiek funkcji, o ile nie opuści nieruchomości lub mieszkania należącego do uchodźcy albo będącego pod opieką organu właściwego w sprawach mieszkaniowych lub ministerstwa ds. uchodźców.

Kolejne ograniczenie ma związek z decyzjami Wysokiego Komisarza, który w BiH odgrywa bardzo ważną rolę w sprawowaniu władzy. Dana osoba mianowicie nie może kandydować ani sprawować mandatu czy jakiejkolwiek funkcji, jeżeli została usunięta przez Wysokiego Komisarza z jakiegoś publicznego stanowiska z powodu złamania postanowień z Dayton ${ }^{32}$.

W przypadku Bośni i Hercegowiny prawo wyborcze przewiduje zasady postępowania na wypadek powstania wakatu w składzie prezydencji. Wraz z prawem o uzupełnienie mandatu opróżnionego przez członka prezydencji

\footnotetext{
${ }^{30}$ R. Mojak, Prezydent Rzeczypospolitej Polskiej, [w:] Polskie prawo konstytucyjne, red. W. Skrzydło, Wydawnictwo UMCS, Lublin 1998, s. 301.

${ }^{31}$ B. Dziemidok-Olszewska, Instytucja prezydenta w państwach Europy Środkowo-Wschodniej, Wydawnictwo UMCS, Lublin 2003, s. 197.

${ }^{32}$ A. Frankiewicz, op. cit., s. 49.
} 
w trakcie kadencji reguluje ono sposób postępowania w rozmaitych sytuacjach. Do powstania wakatu w składzie prezydencji może dojść wówczas, gdy:

- członek prezydencji zostanie usunięty na mocy decyzji Wysokiego Komisarza (na przykład Ante Jelavić i Dragan Čović);

- Sąd Konstytucyjny orzeknie o istnieniu stałej niezdolności do wykonywania obowiązków przez członka prezydencji;

- Sąd Konstytucyjny orzeknie o tymczasowej niezdolności do wykonywania obowiązków przez członka prezydencji;

- członek prezydencji podejmie decyzję o rezygnacji z zajmowanego urzędu (na przykład Alija Izetbegović w 2000 roku, Mirko Šarović w 2003 roku);

- zostanie uznane, iż członek prezydencji zrezygnował z zajmowanego urzędu, co następuje, gdy w ciągu dwunastu miesięcy opuścił on 1/3 przepisowo ustanowionych sesji prezydencji $\mathrm{BiH}^{33}$.

W przypadku wakatu art. V ust. 1 Konstytucji Bośni i Hercegowiny przewiduje konieczność uzupełnienia wakatu poprzez wybór nowego członka zgodnie z procedurą przyjętą na drodze ustawy przez Skupsztynę parlamentarną. Ustrojodawca postawił warunek, iż musi to być kandydat z tej samej jednostki i tej samej narodowości co ustępujący. Parlamentarzyści uchwalili odpowiednią ustawę, jednak została ona bardzo szybko zmieniona przez Wysokiego Przedstawiciela. Po kolejnych nowelizacjach, od 2002 roku obowiązuje przepis, zgodnie z którym nowego członka Prezydium powołują spośród siebie ci deputowani do niższej izby parlamentu, którzy zostali wybrani z tej samej jednostki i są tej samej narodowości. Wybór muszą jeszcze zaakceptować deputowani do izby wyższej, także pochodzący z tego samego narodu konstytutywnego. Ich ewentualny dwukrotny sprzeciw oznacza, że ostateczną decyzję podejmuje niższa izba parlamentu ${ }^{34}$.

Ostatnie wybory w 2014 roku odbywały się w bardzo trudnej sytuacji gospodarczej i w atmosferze powszechnego niezadowolenia. Na wiosnę w Bośni i Hercegowinie doszło do gwałtownych rozruchów i protestów przeciwko skutkom rabunkowej prywatyzacji, zamykaniu fabryk i korupcji. Niepokoje ogarnęły ponad trzydzieści miast. Uczestnicy protestów oskarżali władze o nepotyzm i doprowadzenie do zamknięcia lub upadku $80 \%$ prywatyzowanych zakładów, co spowodowało ponad $40 \%$ bezrobocie w kraju. Do polityków mieli pretensje, że są zbyt wysoko opłacani, oderwani od rzeczywistości i mają obsesję na punkcie sporów etnicznych, choć od wojny w Bośni minęły już lata.

${ }^{33}$ A. Frankiewicz, Ewolucja prawa wyborczego do prezydencji Bośni i Hercegowiny i jej uwarunkowania społeczno-polityczne, „Acta Universitatis Wratislaviensis”, No 3322, „Przegląd Prawa i Administracji" LXXXV, Wrocław 2011, s. 88.

${ }^{34}$ K. Krysieniel, W сіеniu Dayton..., op. cit., s. 266. 
Wybory nie zmieniły napiętej sytuacji politycznej. Wybierano przedstawicieli do parlamentu państwowego, parlamentów entitetów i kantonów. Zgodnie z decyzjami społeczeństwa u władzy utrzymali się nacjonaliści. W wyborach na urząd głowy państwa, reprezentowanej przez trzyosobowe prezydium, wśród Boszniaków wygrał po raz kolejny Bakir Izedbegović (33,16\%), który stoi na czele Partii Akcji Demokratycznej SDA (Stranka Demokratske Akcije). Polityk ten wyprzedził o 6,5\% swojego rywala, magnata medialnego, Fahrudina Radončicia. W Prezydium BiH zasiedli także reprezentujący Republikę Serbską: Mladen Ivanie (48,7\%) oraz Dragan Čović, Chorwat z HDZ BiH, który uzyskał $52,2 \%$ głosów z listy chorwackiej ${ }^{35}$.

B. Izedbegović i D. Ćović zasiadali już w Prezydium i mają odmienne wizje co do przyszłości Bośni i Hercegowiny. Pierwszy to syn Aliji Izedbegovića, przywódcy bośniackich muzułmanów z czasu wojny, i, podobnie jak nieżyjący już ojciec, opowiada się za Bośnią jako silnym i jednolitym państwem. B. Izetbegović, będący członkiem Prezydium od 2010 roku, już zapowiedział, że podstawowym celem na nadchodzącą kadencję będzie dla niego ożywienie starań BiH o akcesję do NATO i UE. „Pora zakończyć ten stupor - sądzę, że politycy dorośli już wystarczająco, by wyjść z tego błędnego koła" - stwierdził w niedzielę 12 października. D. Čović też ma już doświadczenie w Prezydium - był jego członkiem w latach 2002-2005. Odszedł jednak nie na skutek przegranych wyborów, a w atmosferze skandalu - ówczesny Wysoki Przedstawiciel dla Bośni i Hercegowiny Paddy Ashdown odwołał go ze stanowiska z uwagi na oskarżenia o korupcję. Przeciwko D. Čovićowi w następnych siedmiu latach toczyły się trzy oddzielne procesy o korupcję i nadużywanie władzy, ale został ostatecznie uniewinniony. Od 2012 roku pełni on rolę przewodniczącego Izby Narodów, wyższej izby parlamentu BiH. D. Čović postrzegany jest jako chorwacki nacjonalista. W kampanii wyborczej zapowiadał utworzenie dla Chorwatów oddzielnego kraju w BiH - o podobnej strukturze, jaką ma Republika Serbska. Pomijając dążenie do większej autonomii Chorwatów, większość poglądów D. Čovića jest centroprawicowa - jego partia, Chorwacka Unia Demokratyczna Bośni i Hercegowiny, jest obserwatorem w Europejskiej Partii Ludowej ${ }^{36}$. Nowym przedstawicielem w Prezydium Bośnii i Hercegowiny, co jest zaskoczeniem tych wyborów, jest Mladen Ivanić startujący z ramienia opozycyjnego bloku „Związek dla zmian”. Pokonał on faworyzowaną i mającą nacjonalistyczne poglądy dotychczasową

${ }^{35}$ D. Gibas-Krzak, Bośnia i Hercegowina: determinanty dziejów. Pomiędzy Serbami, Chorwatami a supremacja Muzułmanów, Wydawnictwo im. Stanisława Podobińskiego Akademii im. Jana Długosza, Częstochowa 2016, s. 193.

${ }^{36}$ Podzielona Bośnia i Hercegowina, http://www.euractiv.pl/section/polityka-zagraniczna/ news/podzielona-bosnia-i-hercegowina/, dostęp 12 XI 2016. 
premier Republiki Serbskiej Żeljke Cvijanović. Wybrani zostali też deputowani do 42-osobowego Zgromadzenia Parlamentarnego BiH, które reprezentuje narody zamieszkujące ten $\mathrm{kraj}^{37}$.

Tabela 1

Prezydencja Bośni i Hercegowiny, lata 1995-2017

\begin{tabular}{|l|c|c|}
\hline \multicolumn{3}{|c|}{ Prezydent BiH } \\
\hline Imię i nazwisko & Kadencja & Przynależność partyjna \\
\hline Alija Izetbegović & $3.03 .1992-5.10 .1995$ & Partia Akcji Demokratycznej \\
\hline
\end{tabular}

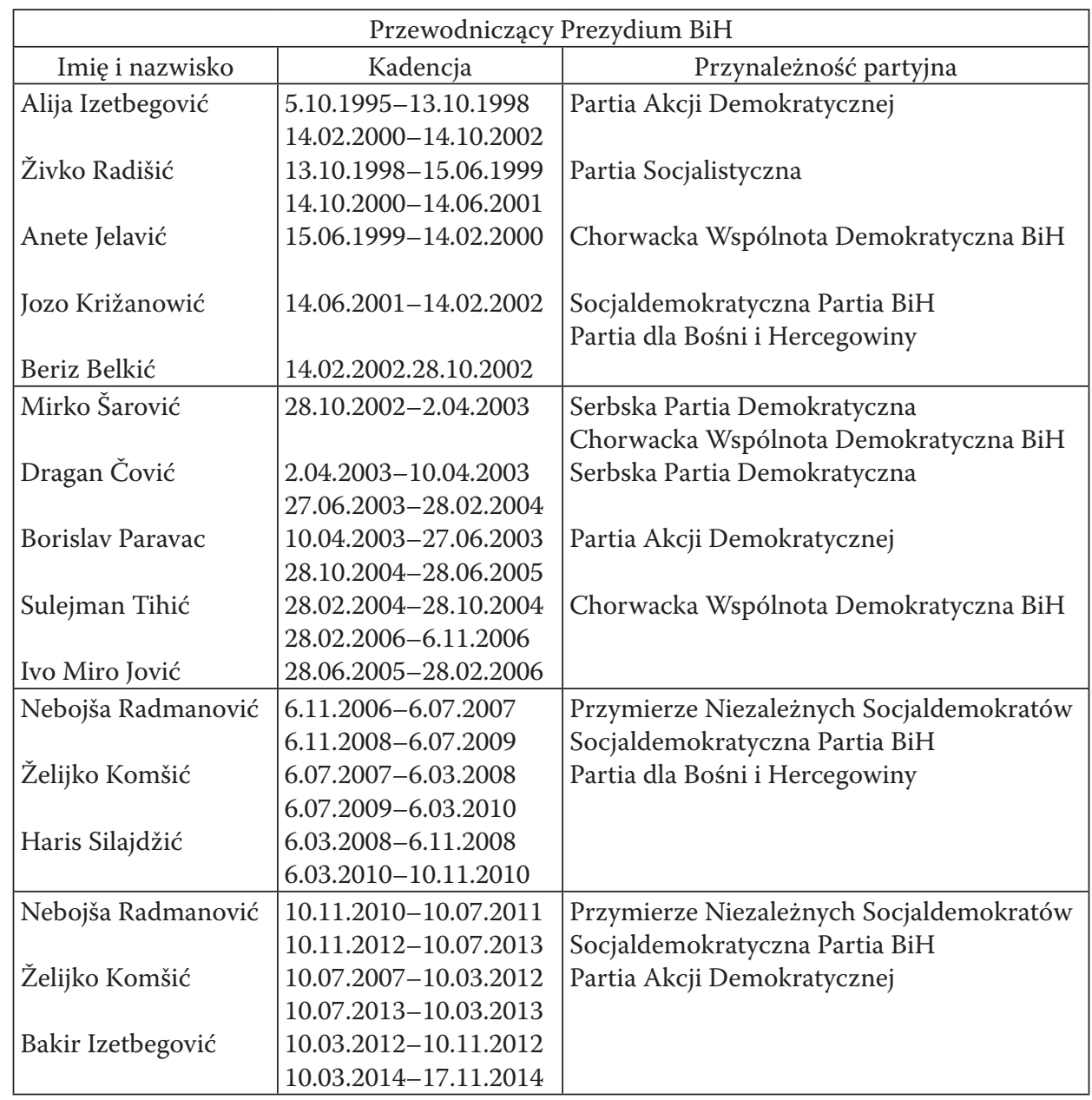

${ }^{37}$ T. Kowalczewski, Oficjalne wyniki wyborów w Bośni i Hercegowinie, http://www.bankier.pl/ wiadomosc/Oficjalne-wyniki-wyborow-w-Bosni-i-Hercegowinie-3225842.html, dostęp 15 III 2017. 


\begin{tabular}{|l|c|l|}
\hline \multicolumn{3}{|c|}{ Przewodniczący } \\
\hline \multicolumn{1}{|c|}{ Imię i nazwisko } & \multicolumn{1}{|c|}{ Kadencja } & \multicolumn{1}{c|}{ Przynależność partyjna } \\
\hline Mladen Ivanić & $17.11 .2014-17.07 .2015$ & $\begin{array}{l}\text { Partia Demokratycznego Rozwoju } \\
\text { Chorwacka Wspólnota Demokratyczna BiH } \\
\text { Dragan Čović }\end{array}$ \\
Bakir Izetbegowvć & $17.07 .2015-17.03 .2016$ & Partia Akcji Demokratycznej \\
Mladen Ivanić & $17.03 .2016-17.11 .2016$ & Partia Demokratycznego Rozwoju \\
Dragan Čović & $17.07 .2017-$ nadal & Chorwacka Wspólnota Demokratyczna BiH \\
\hline
\end{tabular}

Źródło: opracowanie własne na podstawie Oficjalnej Strony Prezydium Bośni i Hercegowiny, http:// www.predsjednistvobih.ba/hron/default.aspx?id=10074\&langTag=en-US, dostęp 20 II 2017.

\section{Kompetencje głowy państwa}

Kolektywna Prezydencja w Bośni i Hercegowinie jest niezwykłym rozwiązaniem. Funkcja reprezentacyjna głowy państwa jest bowiem łatwiej wykonywana przez jedna osobę. Na czele egzekutywy istnieje już jedno kolegialne ciało Rada Ministrów. Dodanie drugiej kolegialnej instytucji wydaje się niesprzyjające efektywnemu podejmowaniu decyzji. Prowadzi to do wzrostu ryzyka powielania procesu podejmowania decyzji, a jednocześnie rozróżnienia kompetencji Rady Ministrów od tych Prezydencji staje się coraz trudniejsze ${ }^{38}$.

Prezydent reprezentuje Federację oraz jest szefem Federalnej Władzy Wykonawczej. Posiada dwóch wiceprezydentów z różnych dwóch narodów konstytucyjnych. Wybierani są razem z jednej listy wyborczej przez obie izby parlamentu Federacji.

Do kompetencji Prezydium, określonych w konstytucji BiH, należą: realizacja polityki zagranicznej $\mathrm{BiH}$; mianowanie ambasadorów i innych przedstawicieli $\mathrm{BiH}$ za granicą (tu po raz kolejny pojawia się parytet: z FBiH może pochodzić najwyżej 2/3 personelu dyplomatycznego); reprezentowanie $\mathrm{BiH}$ na zewnątrz; negocjowanie ze Zgromadzeniem Parlamentarnym umów międzynarodowych, a następnie ich ratyfikowanie; wykonywanie decyzji Zgromadzenia Parlamentarnego; proponowanie budżetu (po rekomendacji rządu); raportowanie parlamentowi, co najmniej raz w roku, wydatków władzy wykonawczej; koordynowanie współpracy z organizacjami międzynarodowymi i pozarządowymi na terenie $\mathrm{BiH}$; wykonywanie wszelkich innych zadań, zleconych przez parlament lub części składowe $\mathrm{BiH}^{39}$.

${ }^{38}$ J. Muś, op. cit., s. 96-96.

${ }^{39}$ P. Timofiejuk, Ustrój polityczny Republiki Bośni i Hercegowiny w myśl porozumień z Dayton, [w:] Bałkany. Etnokulturowe podtoże konfliktów, red. W. Konarski, A. Koseski, Wyższa Szkoła Humaniastyczna im. A. Gieysztora, Pułtusk 2006, s. 176-177. 
W stosunku do parlamentu Prezydium:

- wykonuje decyzje Skupsztyny parlamentarnej;

- przedstawia parlamentowi, na wniosek Rady Ministrów, projekt budżetu;

- składa sprawozdanie z działalności przynajmniej raz w roku ${ }^{40}$.

W systemie parlamentarno-gabinetowym powoływanie premiera należy do kompetencji prezydenta, lecz margines jego swobody jest niewielki z uwagi na ugruntowane prawo sprawowania funkcji rządowych przez partie lub koalicję posiadającą poparcie większości parlamentarnej ${ }^{41}$.

Prezydium Bośni i Hercegowiny nominuje premiera, który, za aprobatą większości Izby Reprezentantów, tworzy Radę Ministrów Bośni i Hercegowiny, czyli centralny rząd, składający się z dziewięciu ministrów (w tym najwyżej sześciu z FBiH). Zarówno premier, jak i ministrowie mają po dwóch zastępców i tu również obowiązuje parytet narodowościowy, co ma na celu zapewnienie wszystkim narodom konstytucyjnym równego udziału w sprawowaniu władzy na szczeblu centralnym. Do podjęcia jakiejkolwiek decyzji potrzebna była zgoda wszystkich trzech, to jest premiera/ministra i jego zastępców, ponieważ tak, jak w przypadku Prezydium, w istocie byli oni sobie równi (ich także dotyczyła zasada rotacji) - dopiero w 2002 roku Wysoki Przedstawiciel zniósł tę zasadę ${ }^{42}$.

Kompetencje prezydenta w stosunku do władzy sądowniczej są znacznie skromniejsze niż w stosunku do parlamentu czy rządu z uwagi na szczególną pozycję i znaczną niezależność władzy sądowniczej. Uprawnienia prezydenta dotyczą głównie prawa łaski, powoływania sędziów i organów władzy sądowniczej, co należy do tradycyjnych atrybutów głowy państwa, a także występowania z wnioskami do Sądów Konstytucyjnych i Trybunałów.

Prawo występowania z wnioskami do Sądów Konstytucyjnych i Trybunałów przysługuje prezydentowi jako organowi czuwającemu nad przestrzeganiem konstytucji. Prezydent dysponuje uprawnieniami pozwalającymi mu uruchamiać kontrolę praworządności aktów prawnych i działań innych organów ${ }^{43}$.

Sędziowie Sądu Konstytucyjnego Bośni i Hercegowiny (trzech) nominowani są przez prezesa Europejskiego Trybunału Praw Człowieka w porozumieniu z prezydencją. Należy zauważyć, że jest to jeden z nielicznych organów w Bośni i Hercegowinie, przy powoływaniu którego ustawa zasadnicza nie narzuca żadnych wymogów co do przynależności etnicznej sędziów, mających być wybrani spośród obywateli państwa (sześciu spośród dziewięciu - trzech musi pochodzić spoza Bośni i Hercegowiny oraz krajów sąsiednich).

\footnotetext{
${ }^{40}$ K. Krysieniel, W cieniu Dayton..., op. cit., s. 263.

${ }^{41}$ B. Dziemidok-Olszewska, op. cit., s. 241.

${ }^{42}$ W. Walkiewicz, Jugostawia. Państwa sukcesyjne, Wydawnictwo Trio, Warszawa 2009, s. 353.

${ }^{43}$ Ibidem, s. 263.
} 
Sprawy do rozpatrzenia kierować mogą do Sądu Konstytucyjnego następujące podmioty: Prezydium BiH, premier Rady Ministrów BiH, przewodniczący bądź jego zastępca każdej z izb Zgromadzenia Parlamentarnego, 1/4 członków którejkolwiek z tych izb, a także 1/4 członków którejkolwiek z izb parlamentów obu podmiotów $\mathrm{BiH}$.

Prezydium Bośni i Hercegowiny podejmuje decyzje w drodze konsensusu. Jeśli jeden z członków Prezydium zgłosi swój sprzeciw wobec decyzji, po trzech dniach referowana ona jest odpowiednio przed Zgromadzeniem Narodowym RS lub Izbą Narodów FBiH. W sytuacji, gdy 2/3 głosujących opowie się przeciwko decyzji, zostaje ona odrzucona. Oznacza to, że blokowanie decyzji Prezydium jest stosunkowo łatwe. Możemy więc powiedzieć o trzech kolektywnych graczach weto, tworzonych przez jednego z członków Prezydencji, oraz grupę posłów reprezentujących odpowiednią etnofrakcję na poziomie entyterów ${ }^{44}$.

Członek Prezydencji, który reprezentuje jedną z grup narodowościowych, musi polegać na poparciu rodaków z parlamentu regionalnego (na poziomie entiterów), w celu skutecznego użycia swojej broni - prawa weta. Boszniacki członek Prezydencji nie potrzebuje głosów serbskich czy chorwackich ani aby zostać wybranym, ani aby skorzystać z prawa weta. Taka sytuacja nie sprzyja współpracy i pojednaniu między trzema narodami $\mathrm{BiH}$.

Członkowie Prezydium wchodzą też w skład Stałego Komitetu do spraw Wojskowych, regulującego wszelką aktywność militarną na obszarze BiH. Miało to szczególne znaczenie w sytuacji, kiedy na terytorium państwa faktycznie funkcjonowały dwa odrębne systemy wojskowe i trzy armie: serbska, bośniacka i chorwacka. Dopiero w 2003 roku, nie bez nacisków ze strony Wysokiego Przedstawiciela, zapadła decyzja o utworzeniu ogólnopaństwowego ministerstwa obrony i ujednoliceniu sił zbrojnych - proces ten trwał kilka lat ${ }^{45}$.

\section{Odpowiedzialność głowy państwa}

Instytucja odpowiedzialności konstytucyjnej prezydenta została wprowadzona przez większość demokratycznych konstytucji państw europejskich. Jednakże w przypadku Bośni i Hercegowiny ustawa zasadnicza nie przewiduje żadnej

\footnotetext{
${ }^{44}$ Zob. M. Sahadžić, „Veto mehanizmi” u parlamentima na državnoj i entitetskoj razini u BiH, „Parlamentarizam u Bosni i Hercegovini”, ed. S. Gavrić, D. Banović, Sarajevski otvoreni centar, Friedrich Ebert Stiftung, Sarajevo 2012, p. 313.

${ }^{45}$ V. Stojarová, Problem bośniacki a szerzej rozumiane bezpieczeństwo. Strony i reprezentacja interesów w Bośni i Hercegowinie, [w:] Europejski protektorat? Bośnia i Hercegowina w perspektywie środkowoeuropejskiej, red. M. Gniazdowski, Polski Instytut Spraw Międzynarodowych, Warszawa 2008, s. 64-66; zob. J. Muś, op. cit., s. 97-98.
} 
możliwości odwołania osób zajmujących najwyższe stanowiska w państwie: czy to członków kolegialnego Prezydium BiH, czy też Rady Ministrów. Takiej prawnej możliwości nie przewidują także akty prawne niższego rzędu.

Brak podstaw i odpowiednich narzędzi dla zastosowania procedury impeachmentu nie oznacza jednak, że nie ma możliwości odsunięcia ze stanowisk polityków zajmujących najwyższe stanowiska w państwie. Jednakże sposób, dzięki któremu taka procedura może mieć miejsce, wskazuje na potraktowanie $\mathrm{BiH}$ jako protektoratu, a nie niepodległego i suwerennego państwa. Ponieważ odpowiednie kompetencje posiada Urząd Wysokiego Przedstawiciela Międzynarodowego ${ }^{46}$. W ramach tzw. „uprawnień bolońskich” Wysoki Przedstawiciel uzyskał między innymi możliwość odwoływania wszelkich osób sprawujących funkcje publiczne, jeżeli stanowią one zagrożenie dla przebiegu procesu pokojowego. Od 1997 roku na mocy „uprawnień bolońskich” kolejni Wysocy Przedstawiciele zdecydowali o wielu dymisjach, w tym dwukrotnie o pozbawieniu mandatu reprezentujących Chorwatów członków Prezydium BiH: Antu Jelavicia w 2001 roku oraz Dragana Čovicia w 2005 roku. ${ }^{47}$

Analizując pozycję ustrojową prezydenta w systemie ustrojowym państw postjugosłowiańskich, możemy wnioskować, iż głowa państwa jest postrzegana raczej jako symbol i gwarant narodowej i państwowej tożsamości oraz czynnik integrujący obywateli republiki. Trafne spostrzeżenia na ten temat wyraża M. Ribariča, wskazując na to, iż „prezydent poprzez przemówienia publiczne jednoczy obywateli kraju w ich przynależności do państwa jako zorganizowanej społeczności. Poprzez wystąpienia publiczne, prezydent republiki promuje podstawowe wartości cywilizacyjne - przede wszystkim szacunek dla praw człowieka i podstawowych wolności - konsoliduje świadomość przynależności narodowej i należenia do społeczności międzynarodowej, umacnia zasady demokracji, rządy prawa [...], szacunek dla odmiennych postaw i tolerancję wśród ludzi"48.

${ }^{46}$ K. Krysieniel, Formy odpowiedzialności konstytucyjnej w Bośni i Hercegowinie, [w:] Formy odpowiedzialności konstytucyjnej w państwach europejskich, red. S. Grabowska, R. Grabowski, Wolters Kluwer Polska, Torun 2010, s. 66.

${ }^{47}$ Ibidem, s. 67.

${ }^{48}$ M. Ribarič, Status of the President of the Republic of Slovenia in the system of government, [w:] Ten years of the Constitutionalism in Central and eastern Europe, red. K. Działocha, R. Mojak, K. Wójtowicz, Wydawnictwo „Morpol”, Lublin 2001, s. 78. 


\section{Bibliografia}

\section{Źródła}

- Constitution of Bosnia and Herzegovina, strona internetowa Urzędu Wysokiego Przedstawiciela, http://www.ohr.int, dostęp 10 VII 2015.

- Dayton Peace Agreement, http://peacemaker.un.org/sites/peacemaker.un.org/files/ BA_951121_DaytonAgreement.pdf, dostęp 3 VI 2016.

- Rules of Procedure of Presidency of Bosnia and Herzegovina, http://www.predsjednistvobih.ba, dostęp 15 III 2017.

\section{Piśmiennictwo naukowe}

- Babić M., Bałkanizacja czy europeizacja? Bośnia i Hercegowina w perspektywie europejskiej, [w:] Konflikty narodowe i europejskie aspiracje państw bałkańskich, red. M. Filipowicz, „Rocznik Instytutu Europy Środkowo-Wschodniej” 2011, rok 9, zeszyt 2.

- Babić M., Bośnia i Hercegowina - specyfika systemu politycznego, Popławski D. (red.), Małe państwa Europy, specyfika systemu politycznego i aktywności międzynarodowej, Oficyna Wydawnicza Aspra-IR, Warszawa 2009.

- Banac I., What happened in the Balkans (or rather ex Yugoslavia)?, "East European Politics and Societies", 2009, nr 4.

- Dziemidok-Olszewska B., Instytucja prezydenta w państwach Europy Środkowo- Wschodniej, Wydawnictwo UMCS, Lublin 2003.

- Fiszer M., Proces kształtowania się statusu Dystryktu Brczko po zakończeniu konfliktu w Bośni i Hercegowinie, „Poliarchia”, 2016, nr 1(6).

- Frankiewicz A., Ewolucja prawa wyborczego do prezydencji Bośni i Hercegowiny i jej uwarunkowania społeczno-polityczne, „Acta Universitatis Wratislaviensis”, No 3322, Przegląd Prawa i Administracji LXXXV, Wrocław 2011.

- Frankiewicz A., Prawo wyborcze do prezydencji w Bośni i Hercegowinie, [w:] Prawo wyborcze na urzad prezydenta w państwach europejskich, red. S. Grabowska, R. Grabowski, Wolters Kluwer Polska, Warszawa 2007.

- Gibas-Krzak D., Bośnia i Hercegowina: determinanty dziejów. Pomiędzy Serbami, Chorwatami a supremacją Muzutmanów, Wydawnictwo im. Stanisława Podobińskiego, Częstochowa 2016.

- Kowalczewski T., Oficjalne wyniki wyborów w Bośni i Hercegowinie, http://www.bankier.pl/wiadomosc/Oficjalne-wyniki-wyborow-w-Bosni-i-Hercegowinie-3225842.html, dostęp 15 III 2017.

- Krysieniel K., W cieniu Dayton. Bośnia i Hercegowina między etnokracją i demokracja konsocjalna, Wydawnictwo Sejmowe, Warszawa 2012.

- Krysieniel K., Formy odpowiedzialności konstytucyjnej w Bośni i Hercegowinie, [w:] Formy odpowiedzialności konstytucyjnej w państwach europejskich, red. S. Grabowska, R. Grabowski, Wolters Kluwer Polska, Toruń 2012.

- Krysieniel K., System wyborczy w Bośni i Hercegowinie - spojrzenie krytyczne, „Przegląd Prawa Konstytucyjnego", 2010, nr 1. 
- Krysieniel K., Ucieczka od Dayton? Bośnia i Hercegowina w procesie przemian ustrojowych, [w:] Polska i Europa Środkowa. Demokratyzacja, konsolidacja, europeizacja, red. E. Nowak, R. Riedel, Wydawnictwo UMCS, Lublin 2010.

- Krysieniel K., Wielokulturowość Bośni i Hercegowiny i jej wptyw na ustrój państwa, [w:] Wspótczesne państwo. Wybrane problemy, red. S. Wróbel, Wyższa Szkoła Bankowa, Poznań 2009.

- Mojak R., Prezydent Rzeczypospolitej Polskiej, [w:] Polskie prawo konstytucyjne, red. W. Skrzydło, Wydawnictwo „Morpol”, Lublin 1998.

- Muś J., Bośnia po wyborach, „Stosunki Międzynarodowe”, 2010, nr 69.

- Olchowski J., Pawłowski K., Region Europy Południowo-Wschodniej, [w:] Regiony w stosunkach międzynarodowych, red. I. Topolski, H. Dumała, A. Dumała, Wydawnictwo UMCS, Lublin 2009.

- Podzielona Bośnia i Hercegowina, http://www.euractiv.pl/section/polityka-zagraniczna/news/podzielona-bosnia-i-hercegowina/, dostęp 12 XI 2016.

- Pomykalska B., Suwerenne państwo pod nadzorem. Rzeczywistość polityczna Bośni i Hercegowiny 17 lat po Dayton, „Państwo i Społeczeństwo”, 2011 (XI), nr 4.

- Ribarič M., Status of the President of the Republic of Slovenia in the system of government, [w:] Ten years of the Constitutionalism in Central and eastern Europe, red. K. Działocha, R. Mojak, K. Wójtowicz, Wydawnictwo „Morpol”, Lublin 2001, s. 78.

- Sahadžić M., "Veto mehanizmi” u parlamentima na državnoj i entitetskoj razini u BiH, „Parlamentarizam u Bosni i Hercegovini“ ed. S. Gavrić, D. Banović, Sarajevski otvoreni centar, Friedrich Ebert Stiftung, Sarajevo 2012.

- Sochacki Sz., Bośnia i Hercegowina 1995-2012. Studium politologiczne, Toruń 2015.

- Stanisławski W., Bośnia i Hercegowina, [w:] Bałkany Zachodnie a integracja europejska. Perspektywy i implikacje, red. R. Sadowski, J. Muś, Urząd Komitetu Integracji Europejskiej, Warszawa 2008.

- Stojarová V., Problem bośniacki a szerzej rozumiane bezpieczeństwo. Strony i reprezentacja interesów w Bośni i Hercegowinie, [w:] Europejski protektorat? Bośnia i Hercegowina w perspektywie środkowoeuropejskiej, red. M. Gniazdowski, Warszawa 2008.

- Timofiejuk P., Ustrój polityczny Republiki Bośni i Hercegowiny w myśl porozumień z Dayton, [w:] Batkany. Etnokulturowe podtoże konfliktów, red. W. Konarski, A. Koseski, Wyższa Szkoła Humaniastyczna im. A. Gieysztora, Pułtusk 2006.

- Vanderwerf M., National Identity in Bosnia-Herzegovina. Part 1: Framework for Exploration, http://www.globalmissiology.org/portugues/docs_pdf/featured/vanderwerf_national_identity_bosnia-herzegovina_part1_2_2009.pdf, dostęp 10 X 2015.

- Vlaisavlević U., Bośnia i Hercegowina: ciagłość etnopolityki w wieku integracji europejskiej, [w:] Rok 1989-20 lat później: kraje postkomunistyczne a integracja europejska, red. M. Ebertowski, Przedstawicielstwo Fundacji im. H. Bölla, Warszawa 2009.

- Vogel T.K., Bosnia and Herzegovina: The Challenge of Legitimacy, „Working Paper”, 2006, nr 2.

- Yiftachel O., Etnocracy. Land and Indentity Polititcs In Israel/Palestine, University of Pennsylvania Press, Philadelfia 2006.

- Walkiewicz W., Jugostawia. Państwa sukcesyjne, Wydawnictwo Trio, Warszawa 2009.

- Wojnicki J., Prawo wyborcze na urzad prezydenta republiki w Republice Serbii, [w:] Prawo wyborcze na urzad prezydenta w państwach europejskich, red. S. Grabowska, R. Grabowski, Wolters Kluwer Polska, Warszawa 2007. 
Podsumowanie: Przedmiotem analizy jest pozycja ustrojowa głowy państwa w Bośni i Hercegowinie. Państwo posiada specyficzne rozwiązania ustrojowe, które zostały ustanowione w wyniku porozumienia w Dayton. Głowę państwa stanowi trzyosobowe prezydium składające się z Serba, Chorwata i Bośniaka. W artykule zaprezentowano procedurę wyborczą, kompetencje i odpowiedzialność tej wyjątkowej Prezydencji.

Słowa kluczowe: Prezydencja Bośni I Hercegowiny, Bośnia i Hercegowina, system polityczny, głowa państwa

\section{The Political Position of the Head of State in Bosnia and Herzegovina}

Summary: The subject of the analysis is the political position of the head of state in Bosnia and Herzegovina. The State has specific systemic solutions that have been established as a result of the Dayton agreement. The three presidency members are from the three constituent nations one Bosniak, one Serb, one Croat. The article presents the electoral procedure, the powers and responsibilities of this unique Presidency.

Keywords: the Presidency of Bosnia and Herzegovina, Bosnia and Herzegovina, political system, the head of state 